\title{
Rather Spirit-filled than learned! Pentecostalism's tradition of anti-intellectualism and Pentecostal theological scholarship
}

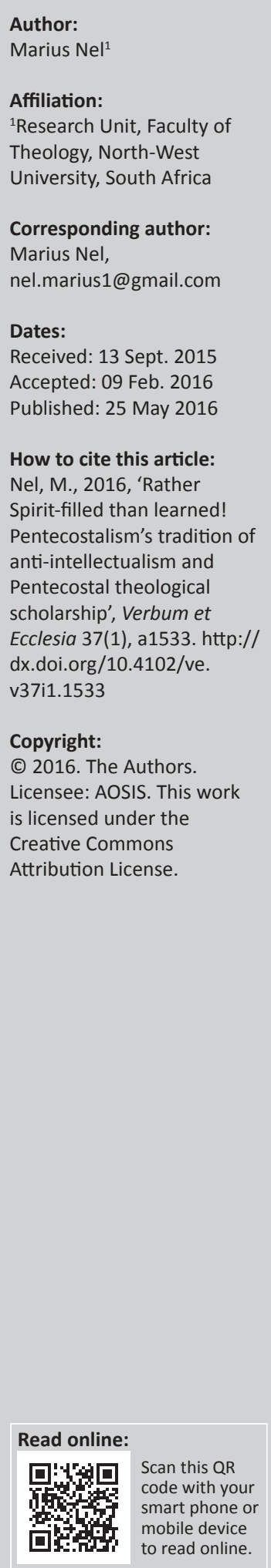

The beginnings and first half-century of South African Pentecostalism are characterised by a tradition of anti-intellectualism consisting of a rejection of theological training, a critical and negative attitude towards theologians, and criticism of the academic world in general. This led to Pentecostals being seen as outsiders without a theological tradition or any contribution to be made to the theological world, or even any interest in developing and formulating a theological structure that can compare or contrast with other theological structures. The historical phenomenon of anti-intellectualism is described in terms of its complicated motivation and nature before the rise of Pentecostal theological scholarship is investigated in terms of its historical development and nature. The article closes with some remarks about the future of Pentecostal theological scholarship.

Intradisciplinary and/or interdisciplinary implications: The article reflects a historical survey of attitudes within the South African Pentecostal churches towards academic endeavours and theological reflection, showing how it changed from anti-intellectualism toward a more positive attitude with certain reservations and allowing for the development of Pentecostal scholarship. For historical reasons South African tertiary education has been closed for Pentecostal scholarship, although the situation will be changing in the near future because of the Pentecostal influence.

\section{Introduction}

John G. Lake, a member of the missionary group that visited South Africa after their experiences at the Azusa Street Revival in Los Angeles ${ }^{1}$ from 1908 to 1913, provides an anecdote about what was supposed to have happened during one of his missionary excursions without mentioning where it happened:

The Boer people were a pioneer people. They did not have the advantages of good schools. About the only educated person in a community was the Dutch Predicant [sic]. He was a real aristocrat, with all the authority that the priests of Ireland exercised over the people there. One day Von Shield ${ }^{2}$ was conducting a service with a couple of hundred people present. The predicant was there. He arose as he was teaching and told the people that they were being misled, and that these things Von Shield was talking about were only calculated for the days of the apostles.

If Von Shield had been an ordinary young man he would have been somewhat nonplussed. But presently he said, 'I will tell you how we will settle this thing. There is Miss LeRoux [sic] whom we all know. She is stone blind in one eye, and has been for four years. I will ask her to come here and I will lay hands upon her and ask the Lord Jesus to make her well'. And picking up his Dutch Bible, he said to her, 'And when He heals you, you will read that chapter', designating the chapter she was to read.

God Almighty met the fellow's faith; the woman's eye opened right then, and she stood before that congregation and covering the good eye, read with the eye that had been blind, the entire chapter. (Lake in Lindsay 1971:58)

The Pentecostal movement originated at the beginning of the 20th century with believers receiving what they perceived to be the baptism in the Spirit, with the accompanying speaking in tongues (Walker 1993:429). As demonstrated by Lake's anecdote that cannot be verified, the early membership of Pentecostal assemblies did not consist of professional people; poor and

1.Not all Pentecostal movements trace their lineage to Seymour's Azusa Street mission or Parham's initiative, as Asamoah-Gyadu (2005:11) argues. Pentecostalism is also not exclusively an American export. In the documentation of the history of Pentecostalism, the origins of the movement in different contexts across the world should be distinguished from the efforts of its American versions to globalise knowledge of it (Anderson 2012:162-166). However, the AFM was one of the results of American Pentecostalism's missions globalise knowledge of it (Anderson 2012 .
outreaches (Chandomba 2007:14-15)

2.Von Shield (Lake does not provide the Christian name) was a book agent who became a Pentecostal convert under the ministry of John G. Lake when he was baptized in the Spirit, and then he spent his time preaching the Pentecostal message (Lindsay 1971:56). 
disenfranchised people, the peasants, artisans, and labourers constituted the members of the new movement. ${ }^{3}$ In most instances many of these believers were either illiterate or theologically illiterate, although they immediately started witnessing about the Pentecostal blessing they had received (Anderson 1979:77). What was important was to be Spiritfilled rather than to be learned. Some of them became leaders in assemblies that grew from their witnessing work. In the first years they did not place much value on literacy and higher education because they did not have the privilege of such education.

\section{According to Möller (1975):}

Many of the parents came from the working class and they argued, why should their children be something other than what they themselves are ... Pentecostals told me that they wanted to study when they were young, but their parents argued in the following way, you cannot waste your time at university while the Lord may come at any moment. (p. 272) ${ }^{4}$

One of the results is that there existed no Pentecostal theological scholarship ${ }^{5}$ during the first half of the 20th century. This changed during the second half of the century with professional scholarly publications that appeared from the 1960s, and an unprecedented increase of Pentecostal scholars during the 1970s, the formation of academic societies among Pentecostals, and the establishment of Pentecostal institutions of higher education.

\section{Classical Pentecostalism's tradition of anti-intellectualism}

The first generation of Pentecostals consisted of the disinherited (Anderson 1979:78) who received the baptism in the Spirit and became convinced of the necessity that each believer should take responsibility for spreading the news of tongue speaking. Every believer is a priest and shares in the commission to build the church and spread the gospel (Langerman 1983:124). Everyone, even youths and children, became involved in witnessing, preaching, singing, worshiping, and praying for the needy and sick (Hammonds 2009:48). Anyone who felt the anointing of the Spirit preached and in worship services it happened many times that more than one person partook, including women. The Pentecostal churches expected all who were born again to witness (Burger 1987:181). Nobody received any training; the only qualification for competence to witness about the message of Pentecost was a personal experience of the

3.Molobi (2014:3) refers to them as "the "little people," the blue and white colla workers'. Synan (1997:207) notes that American Pentecostals 'were particularly active in serving the millions of poorer migrants to the larger city', a remark that is also true of the South African Pentecostal movement. What is also remarkable is that early Pentecostals in America and South Africa attended multiracial worship services in an era when racism determined church attendance to a large degree (Chandomba 2007:24)

4.'Baie van die ouers was van die werkende klas en het van die standpunt uitgegaan: waarom moes hulle kinders iets anders wees as wat hulleself is ... Pentekostaliste het aan my vertel dat hulle ook graag wou gaan studeer toe hulle nog jonk was, maar hulle ouers het op die volgende wyse geredeneer: Jy kan nie jou tyd op universiteitsbanke gaan deurbring terwyl die Here een van die dae kom nie'.

5.Theology is defined as the study of God and God's relation with the world, and theological scholarship as the study of the practice and experience of religious devotion. baptism with the Spirit accompanied by speaking in tongues which the believers receive in order to be effective witnesses (Menzies 2007:80) both in Jerusalem, and in all Judaea and Samaria, and unto the uttermost part of the earth (Ac 1:8). In many cases Pentecostal believers felt strongly about the inappropriateness of a formal academic training as a reaction against the cold and formal religious exercises that characterised the learned reverends and churches with their 'lifeless religiosity of denominational Christianity' (Vreeland 2002:5) that had suspended the Pentecostal believers when they received the baptism in the Spirit (Du Plessis 1984:213). ${ }^{6}$ Classical Pentecostals along with the Holiness and Fundamentalist traditions have been dismissed (incorrectly, as Stephenson 2009:2 argues) as a profoundly anti-intellectual movement that strove to achieve spiritual perfection through strong emotional experience (Hunt 2002:13; and as documented by King 2008:69; Noll 1994:109-148). ${ }^{7}$ And Pentecostals confirmed their strong anti-intellectual, anti-academic prejudice, living up to the stereotype cast by many mainline theologians (as Johns 1999:183-197 shows).

Members who served as elders, deacons, or missionaries with distinction were awarded with certificates that acknowledged their gifting (Constitution of the Apostolic Faith Mission of South Africa 1961:284-292; Langerman 1983:125). These members did not have any formal or informal theological qualifications (Wessels 1992:378). At most, short-term Bible schools were held to indoctrinate the new converts and train workers for 'the field'. 'Bible school training' consisted of a basic knowledge of the Bible and its focus was on the application of the content of the Bible in the practice of daily ministry. The Bible was used at face value without complicating its historical data and it was literally interpreted before it was applied pragmatically (Barr 1983:27). It avoided any critical or systematic thinking that is associated with theological or academic expertise because such knowledge was regarded by Pentecostals as endangering the individual's faith and corrupting the church (Chan 2000:45). What was needed was only a thorough knowledge of the Bible combined with the anointing with God's Spirit as the prerequisite to qualify to minister as an evangelist or teacher of the Word. It has been suggested that Pentecostal people might have hidden their feelings of theological inferiority behind the impression of their superior spiritual qualities based on their strong faith in the Word of God excluding the necessity of theological reflection (Morton 2012:113). ${ }^{8}$ Within a few years, more permanent,

6.Niebuhr (1929:30) already identified the reasons for the rise of Pentecostal churches as the rejection of the intellectual and liturgical fixed services of the traditional church, and a preference for a spontaneous form of worship, quite often of a primitive kind.

7.Synan (1971:205, 1997:207) relates Arminian Pentecostals' sympathy with fundamentalist Calvinist leaders' controversy over Darwin's evolutionary theory during the 1920s. Pentecostals shared the deep anti-intellectual bias that distinguished much of conservative Protestantism in this period (King 2008:74).

8.Phillips, Janse van Rensburg and Van Rooy (2012:6-7) remarks that the New Testament authors were inspired by the Holy Spirit to complete the revelation of Testament authors were inspired by the Holy Spirit to complete the revelation of resus Christ (see e.g. Jn 16:13-14), leading to the conclusion that subsequent readers are dependent on the illumination of the Holy Spirit for correct understanding. This means that reading the Bible is a spiritual exercise and not merely an intellectual one. However, with early Pentecostal people there was a conscious avoidance of anything that may look like theological labour. 
longer term schools were established (Anderson 1979:76). However it did not provide any theological education; the purpose was to equip and train persons to evangelise and pastor a church rather than to participate in discussions about complicated theological and philosophical issues (Gee 1932:82).

Early Pentecostals were, in many cases, suspicious of the scholastic tendencies in the mainline Christian churches, as John G. Lake's reference to the 'Dutch predicant'. In the main, the mainline churches looked down upon the leaders of Pentecostal assemblies as unlearnt and uncouth (Vondey 2010a:88-98). ${ }^{9}$ Why did Pentecostalism during the first five decades of its existence develop a tradition of antiintellectualism?

\section{The roots of Pentecostal anti-intellectualism}

A first reason for Pentecostalism's anti-intellectualism is in the historical circumstances in which the movement started, among the poor and dispossessed in South Africa. Most of the early members were illiterate; very seldom did professional people attend meetings of the early Pentecostal churches. The Pentecostal missionaries arrived not long after the South African War (1899-1902) that left a disastrous legacy of poverty (Burger 1987:118). Most members of the Pentecostal churches came from the poor classes and they attended meetings in simple houses and halls made from zinc, mainly in chaotic digger communities and inner cities where people who had lost their land collected (Burger 1987:119). Early Pentecostals lacked the motivation to engage in intellectual activities and organisations (Vondey 2013:134). Many of their leaders can be described as 'amateurs' compelled by their experience of the Spirit to speak and write rather than as trained academicians who obeyed literary rules and scholarly inventions (Jacobsen 2003:8; Menzies 2007:79).

A further reason is in the urgency and determination of Pentecostals in their task of evangelisation, a diligence motivated by a desire to proclaim the gospel of salvation to a world facing the imminent second coming with its judgement seat (Vondey 2013:134). The need to carry the message to the unreached was so urgent that there was no time for training and preparation (Anderson 2007:47-72 discusses these worldwide outreaches that lead him to characterise early Pentecostalism in terms of its missionary nature)..$^{10}$ The gift of speaking in tongues was frequently interpreted as the gift of foreign languages, enabling the receiver to preach the gospel to nations without the need to learn the foreign languages and without the need for further theological or biblical training 9.Van Staden (1980:8-11) provides such an assessment of the pastors of the AFM.

10.The name of the Azusa Street church was the Apostolic Faith Gospel Mission, emphasizing the importance for early Pentecostalism to claim a link with the earliest apostolic churches and of missionary work (McClung 2012:6). In the first edition of the Azusa Street periodical, The Apostolic Faith of September 1906, th lead article headed, 'Los Angeles Being Visited by a Revival of Bible Salvation and Pentecost as Recorded in the Book of Acts', one reads, 'The scenes that are daily enacted in the building on Azusa Street and at missions and churches in other part of the city are beyond description, and the real revival is only started, as God has been working with His children mostly, getting them through to Pentecost, and laying the foundation for a mighty wave of salvation among the unconverted'.
(Cartledge 2012:95-96; McGee 1986:34). ${ }^{11}$ God had given languages 'to the unlearned' (Apostolic Faith, September 1906:1) and equipped the 'simple, unlearned members of the body of Christ' (Apostolic Faith, November 1906:1). The early Pentecostals even went on missionary tours to the areas where they believed they had been equipped to preach, only to find out that their new tongues show no affinity with existing languages (Robeck 2006:21). Their missionary zeal was enthused by divine revelation and motivated by eschatological urgency (Tomlinson 1913:69, 74). There was no time left for a formal educational process when the second coming of the Lord might happen at any moment (Anderson 2007:58; Wacker 2001:31). And the second coming conditionally requires that the gospel be proclaimed to all nations (cf. Faupel's 1996:20-27 important work on the way their eschatological viewpoints determined the missionary zeal of early Pentecostals). Missionaries received minimal training, bypassing college or seminar degree programmes (McGee 1986:35); even when Bible institutes became more prominent from the 1920s, many Pentecostal missionaries left for other countries without credentials or formal studies because of their dependence on the Spirit (Kay \& Dyer 2004:25-46; McGee 2010:153-156). Equipped with the power of the Spirit all believers are qualified to serve as missionaries and proclaimers (Vondey 2010a:33). 'Continual education and dedication to the life of the mind were simply not practical aspects of Pentecostal worldview and spirituality' (Vondey 2013:135).

A third reason is found in the widespread negative perception found among early Pentecostals that an intellectualisation of the Christian faith was resisting or even suppressing the work of the Holy Spirit, while the life of the Spirit and the demands of intellectual labours were seen as opposites that do not readily mix (Price 1999:207). According to a Pentecostal evaluation of the history of the church, the early Christian church eventually institutionalised and intellectualised at the cost of the dynamic power of the Spirit (Spurling 1920:2). The implication is that the Spirit was driven out of the church and replaced with a reliance on intellectual and speculative thinking leading to creeds, theological theories, and criticism that disempowered the gospel and paralysed believers (Tarr 1997:197-198). Formal theological education was evaluated as liberal in contrast to the biblical conservatism of Pentecostals, unbiblical because it represents higher criticism and historical critical methods, formal because it suppressed the spontaneous working of the Spirit, and out of touch with reality, specifically the unique demands that the mission fields set (Vondey 2013:136). These pragmatic, eschatological, and evangelistic convictions challenged Pentecostal theological scholarship (Togarasei 2015:63).

\section{The content of Pentecostal anti-intellectuality}

Anti-intellectualism characterised the niche market that Pentecostalism targeted at the beginning of the 20th century

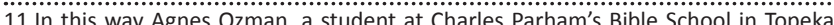
Kansas, started speaking in tongues that we Padentified Kansas, started speaking in tongues that were i . Eventually Pentecostals experienced the disappointment that speaking in tongues did not qualify them to speak in known tongues; it was a prayer language that excluded any communication with humans (Liardon 1996:119). 
in South Africa (Giliomee \& Mbenga 2007:228). Motivated by their evangelistic zeal to preach the gospel and an eschatological pragmatism that centres on the work of the Spirit, Pentecostals were reluctant to participate in academic theological endeavours (Nanez 2005:120). A Pentecostal hermeneutics emphasises three elements: the interrelationship between the Holy Spirit as the One animating Scriptures and empowering the believing community (cp. Archer 2009, 2012:109-110) with the purpose that members be equipped for ministry and witness in culturally appropriate ways (Rance 2008:8). ${ }^{12}$ Even in contemporary times Pentecostal scholars are sceptic about academic scholarship that is overdependent on the intellect at the cost of involving the entire person in the life of faith (Vondey 2013:136). On the one side the pragmatism of the Pentecostal worldview and spirituality finds itself in an awkward position in the academic world (Chan 2010:149); on the other side Pentecostal emphasis on signs and wonders may help reform the current one-sided emphasis on the rational in current academic scholarship (Daniels 2005:112; De Wet 1986:164).

Pentecostal anti-intellectuality rests on several observations that characterised the early days of the Pentecostal movement. Even though these observations are valid for the modern Pentecostal and Charismatic movement it is emphasised in new ways that leaves room for scholarship to develop. A first observation is that Pentecostal spirituality ${ }^{13}$ arises from the affections rather than intellectual ability (Asamoah-Gyadu 2013:24), with an emphasis on the individual's encounter with a living God leading to an emotional and volitional reaction (Becker 2004:38; Chan 2010:150-151; Hunt 2002). Love, passion, desire, feelings, and emotions are emphasised in an attempt to integrate orthopathy with orthodoxy and orthopraxy. The sole rule of the intellect and orthodoxy is rejected (Land 1993:127-133). Pentecostal 'thinking' happens at the level of the affective, unconscious, predeliberative (Asamoah-Gyadu 2013:21) and leaves ample room for the undeterminative working of the Spirit and it is aimed at and subjected to witness and worship before it enters the cognitive, deliberative world of understanding (Smith 2010:72-75). It does not deny the significance of the intellect; it rather rejects its dominance and suggests that more is needed for the full pursuit of knowledge (Vondey 2013:137).

A further observation is that Pentecostal spirituality is dominated by imagination rather than reason (Vondey

12.Cf. Nel (2015) for further discussion. Moore (1987:4) and McQueen (2009:2) emphasizes four aspects of a Pentecostal approach to Scripture: because the Spirit addresses us in ways which transcend human reason, Scripture is not simply an object which we interpret, but a living Word which interprets us; Pentecostal experience of the Spirit is grounded in a relational epistemology where knowing about God and directly experiencing God perpetually inform and depend on one another; the responsibility of each Pentecostal believer to be witness is grounded in a distinct belief in the priesthood and prophethood of all believers: and Scripture is approached communally as the believers oather around the Word in the Spirit to hear what God may say to the assembly of believers.

13.'Spirituality is especially significant for understanding Pentecostalism, since it arguably serves as the primary means for differentiating Pentecostals from other Christian traditions and spiritualities' (Neumann 2012:196). Neumann defines Pentecosta spirituality as experiential, biblical/revelatory, holistic, and missional/pragmatic. 2010a:16-46). It functions on an epistemological level that is aesthetic rather than noetic (Smith 2010:81). The world is viewed in terms of the manifestation of the Spirit, the biblical witness, and the community of faith (Yong 2003:121). Imagination is contrasted to the dominance of reason and order, leaving room for improvisation, play, performance, and instrumentality which stands diametrically opposite of mainline churches as well as the academy's formal disciplines and methodologies (Vondey 2010a:40). An important part of Pentecostal spirituality is its sacramentality that sees reality and looks beyond reality as necessary presuppositions for engaging with the world and participating in its struggles and sufferings rather than isolating itself in an ivory tower of intellectual engagement (Macchia 2010:256-257; Tomberlin 2010:195; Vondey \& Green 2010:247). Pentecostal 'action-reflection in the Spirit' (Land 1993:119) allows for the rational pursuit of meaning but it is doubtful whether reason alone can lead to the discernment of truth (Plüss 2003:17).

A third observation is that Pentecostal spirituality operates on the level of oral rather than written discourse and it is concerned with ongoing, daily revelation of truths in the life of the individual and assembly rather than the revelation of eternal truths. ${ }^{14}$ Pentecostals operate at the limits of speech where the Spirit reveals insights and they are more comfortable with testimony, story, song, preaching, and praise than with definition, concept, thesis, system, philosophy and methodology that dominate scholarly enterprises (Hollenweger 2005:196; Plüss 2003:8-9). Tongue speaking defies categorisation and operates in a realm outside of reality (Smith 2010:150). 'Glossolalia is the flagship of the Pentecostal resistance to the dominance of human language and the discourse of meaning' (Vondey 2013:138). It does not reject human language but questions its ability to capture the world in its manifold dimensions (Cartledge 2012:96).

Its anti-intellectualism does not allow Pentecostals to be stereotyped as rejecting academic enterprises and the intellectual dimensions of life; it allows Pentecostals to be sceptic and uneasy with the purely cognitive, rational, and scientific modes of knowing. Pentecostal 'knowing' consists in terms of dynamic, experiential, and relation knowledge (Johns 1993:12). Its emphasis on the affections, imagination, and the limits of speech define Pentecostalism's antiintellectualism but also the unprecedented rise of Pentecostal theological scholarship during the second part of the 20th century (Hollenweger 1992:44).

14.Hollenweger (1986:3) thinks that the appeal of Pentecostalism's phenomenal growth is rooted in the moorings of its black roots. These moorings include orality of liturgy; narrativity of theology and witness; maximum participation at the levels of reflection, prayer, and decision-making; inclusion of dreams and visions into personal and public forms of worship, and an understanding of the body/mind relationship that is informed by experience of correspondence between body and mind, as demonstrated in the ministry of healing (Hollenweger 1986:7). The holistic interation of spiritual reality in Pentecostalism with the needs and (1) challenges of daily life, including physical healing, power over demons, and miraculous interventions and answers to prayer, make for a potent combination is 2006:28). Clarke (2013:171) agrees that the appeal of Pentecostalism is due to these Pentecostal distinctives, but adds that it also appeals to other aspects of western postmodern culture. 


\section{Classical Pentecostalism's tradition of intellectual participation}

Classical Pentecostalism was perpetuated in the Charismatic renewal of the 1960s with Dennis Bennett, Kevin Ranaghan, and Kathryn Kuhlman in Van Nuys, California, only a few kilometres north of Azusa Street (Harper 2008:108; Tickle 2012:67-69); and invigorated by the third-wave neoCharismatic movement of Peter Wagner and John Wimber in the 1980s (Gabriel 2012:150-154; Synan 2001:177-232) (cf. especially Cox 1995:20, 23-25, 34-42). Pentecostal theological scholarship coincided with the Charismatic movement that also reached college and university students and stirred up questions about the relationship between a Spirit-filled life and academic scholarship (Smith 2010:146150). The 1970s and 1980s saw an increase in Pentecostal studies (Asamoah-Gyadu 2015:15) and the formation of academic societies among Pentecostals (Mittelstadt 2012:913). Where the first decades of the Pentecostal movement were characterised by anti-intellectualism, its modern history is defined by academic contributions and the development of Pentecostal theological scholarship, although Karkkainen (1998:80) argues that because of its fundamentalist heritage, Pentecostalism is marked by a strong anti-intellectualism which persists even to the present day.

The movement was influenced by several attempts at training, such as A.B. Simpson's model of missionary training that influenced the Pentecostal movement (Nienkirchen 1992:43); Walter J. Hollenweger's (1972) work in the 1960s that introduced a wave of Pentecostal historians wishing to preserve the early history of the Pentecostal movement; and the Charismatic movement that encouraged Pentecostals to recover their roots and to confront historiographical models that failed to account for the rise and persistence of modernday Pentecostalism (Vondey 2013:139). From 1970 new developments also led to the change from 'Bible School' training to theological training, a tendency followed by the Pentecostal movement. It accepted that its leaders and pastors should be trained sufficiently to lead believers in a responsible manner; theological training became part and parcel of the development of the professional pastorate and the pastoral theological approach to the church (Burger \& Nel 2008:393). ${ }^{15}$ And as theological training became compulsory for the ordained ministry, the gap between the 'clergy' and 'laity' broadened (Goff 2008:91). Many Pentecostal scholars completed their postgraduate studies, often in an environment that neglected or obstructed the interaction of critical scholarship and Pentecostal faith and praxis (Moore, Land \& Thomas 1992:3). These scholars investigated the biblical sources most relevant to a Pentecostal self-description, particularly Luke-Acts (McQueen 2009:1; Mittelstadt 2010:46-63), cessationism, dispensationalism, Spirit baptism, and hermeneutics as particular Pentecostal concerns (Archer 2009:172-211; Holter 2010:90; Yong 2007:244-250). During the 1990s Pentecostal theological scholarship saw constructive an integrated, Pentecostal liberal education to realize Jesus' call to study and action. theological research with an emphasis on the distinctives of Pentecostal faith, sometimes in the form of apologetics (Moore et al. 1992:3-5), a theology of the Spirit-filled life (Yong 2007:244-250), and a reconsideration of existing doctrines in a more systematic fashion (Yong 2005a:1-15). ${ }^{16}$ Pentecostal theological scholarship has grown beyond the traditional historical and biblical theological conversations (Vondey 2010a:15). The 21st century sees Pentecostal scholarship moving into questions of scientific knowledge and methodology, physics, biology, chemistry, psychology, medicine, anthropology, sociology, and technology (Carstens 2014; Smith \& Yong 2010). The coming of age of Pentecostal scholarship requires that Pentecostals engage in all scientific disciplines and the increasing exposure of the scientific world to the phenomenon of Pentecostalism. Globally Pentecostal seminaries and universities, and locally partnerships between Pentecostal denominations and universities promise a deepening in the involvement of Pentecostals in theological and ecumenical enterprises. ${ }^{17}$

Pentecostal theological scholarship in the 21st century will be defined by several factors. In the first place, Pentecostal theological scholarship is experiential, defined by the foundational dimension of an encounter with the Spirit that determines Pentecostal spirituality and praxis (cf. AsamoahGyadu 2013:30; Warrington 2008). In its contributions to the various theological disciplines Pentecostal theological scholarship endeavours to articulate this normative encounter with God (Yong 2007:244-250). 'The Pentecostal experiences are at the core defined theologically' (Vondey 2013:142). Theology is radically informed by the anticipation that the Spirit can be discovered in all of life and thereby directs all of life toward God (Vondey 2010b:75-91; Work 2010:15-33).

In the second place, Pentecostal theological scholarship operates on the principle of play rather than performance (Vondey 2013:142). Traditional scholarship served under the tyranny of rationalism, seriousness, and work whereas Pentecostal theological scholarship emphasises a playful orientation (Vondey 2010a:171) on the level of 'pure means' or 'pure self-presentation' (Wariboko 2011:165-171). The encounter with God's Spirit in the present leads to restlessness and the anticipation of the kingdom of God where the fullness of life in the Spirit is yet to be realised, with a way of being that is radically open to divine surprises (Macchia

16. Hammonds (2009.56) distinguishes a contemporary form of the Pentecostal movement and calls it Neo-Pentecostalism, and adds that it is characterized by less emphasis on the baptism of the Holy Spirit with the evidence of speaking in emphasis on the baptism of the Holy Spirit with the evidence of speaking in
tongues and more on the power of the Holy Spirit for healing, prophetic utterances, vibrant worship, music, and prosperity for believers (Togarasei 2015:60). In his opinion Neo-Pentecostalism is more flexible and emphasizes a Christian freedom to be led by the Spirit in all aspects of life. I suspect not many theologians would accept Hammonds' generalization (cf. Gabriel 2012:154). Interesting research by Cartledge (2003) indicates that the $24.6 \%$ of the people that he interviewed during his quantitative research who believe that healing will always occur if a person's faith is great enough tend to represent the less-educated people from the lower social class; are the younger and more immature Christians; believe in daily cower social class; are the younger and more immature Christians; believe in daily conflict with demons; tend to be anti-intellectual, preferring intuition and personal Pentecostalism's anti-intellectual tradition should be further investigated.

17.For instance, the partnership between North-West University and several Pentecostal churches like the Apostolic Faith Mission of South Africa, the Full Gospel Church of God, and the Members in Christ Association (Janse van Rensburg \& Nel 2015) 
2010:254; Wariboko 2011:207). Although it does not reject critical reflection, Pentecostal theological scholarship refuses to submit to the exclusive claims of reason's dominance (Vondey 2013:143). Pentecostal theological scholarship is informed by the pneumatological focus inherent in its worldview and spirituality.

Thirdly, Pentecostal theological scholarship is embodied scholarship, requiring the scholar to go beyond the mere intellectual pursuit of knowledge and to participate actively in the community of faith. Embodied scholarship implies interdisciplinary and multidisciplinary inquiry where personal experiences are connected to the community, social structure, and human concerns (Albrecht 1999:210). The Holy Spirit speaks as well in the scholarly pursuits where embodiment seeks the expressions of Charismatic life. The Pentecostal scholar is not an objective observer only; she or he always actively and passionately participates in the research (Yong 2007:248).

Fourthly and lastly, Pentecostal theological scholarship is based on a comprehensive, analogical hermeneutic, what Stibbe (1998:181-193) calls a 'this-is-that' hermeneutic. The present is interpreted in terms of the past, the Christian life in terms of biblical narratives, and the Pentecostal experience in terms of the Day of Pentecost and the experiences of the earliest Church. ${ }^{18}$ Contemporary Pentecostal experiences are defined by way of the principle of analogy in terms of the interpretation of Scripture (Spawn 2011:49). It rejects dominant perceptions of reality in favour of an alternative interpretation, the perceived reality of God, as found in the interpretation of biblical narratives.

The integration of the experiential, playful, embodied, and analogical dimensions of understanding and participation in the world takes Pentecostal scholars to the forefront of the renewal and revitalisation of the postmodern academic world (Vondey 2013:145). These should however be balanced with other theological traditions by way of dialogue.

Contemporary Pentecostalism is neither anti-intellectual nor intellectual; both elements are present among Pentecostals worldwide and in South Africa. And Pentecostal theological scholarship still experiences to a certain extent tension with anti-intellectual strains within Pentecostalism as many Pentecostal scholars would readily testify (Clark 2015:2; Robeck 2004:212-224). The coexistence of both trends is essential if one desires to come to terms with the scope and depth of the Pentecostal ethos with its emphasis on the experiential and lived reality. The temptation will always exist that the Pentecostal scholar may succumb to the rigorous intellectual claims of the academe at the loss of the Pentecostal distinctives (Wenk 2003:62). The elements of a Pentecostal theological distinctive can be described as the necessity that each member of the church is able to testify of conviction of

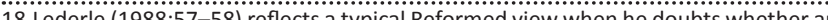
analogy based on the lives of Jesus and his apostles can be maintained in terms of contemporary experience; in his opinion, Jesus and the apostles played a unique contemporary experience; in his opinion, Jesus and the apostles played a unique
and unrepeatable role in salvation history. This is a major point of difference between Pentecostals and the other Christian traditions. sin as a function of the Spirit leading to a personal meeting with God, and the experience that one's sins have been forgiven (Tomberlin 2010:37), leading to the wish and opportunity to witness of salvation; the experience of sanctification (Peretti 1995:ix), as preparation for Spirit baptism (McClung \& Wagner 1986:23-24) that leads to the transformation and empowerment of a fearful and uncertain group of disciples into a missionary fellowship that boldly carry the gospel throughout the world; with speaking in tongues as the (initial) evidence (Tomberlin 2010:46); and healings, exorcisms, and other miracles as proof that the modern church succeeds as Christ's body on earth (Thomas 2010:306-307); and an eschatological expectation (Macchia 2006:112).

It is inevitable that Pentecostals will eventually teach and research at South African universities ${ }^{19}$ although there is not much interest in Pentecostal theological scholarship at the universities where theological faculties are under the sway of existing mainline denominations. Although most academic institutions are not hostile anymore to Pentecostals, it is also true that few Pentecostals are invited to participate in broader academic discussions or projects. And Pentecostals also find it awkward and uncomfortable to associate with institutions that question or contradict the Pentecostal worldview and spirituality. To an important extent Pentecostal theological scholarship forms a counter-culture in the South African theological scene that is dominated to a large extent by the Reformed theological tradition.

It may be that Pentecostal theological scholarship is defined by Spirit baptism with speaking in tongues and evaluated as an interruption of 'proper academic norms and behaviour' (Macchia 1992:48). However, Pentecostal theological scholarship is about much more than tongue speaking, as indicated in the discussion of Pentecostal distinctives above. Pentecostal theological scholarship can rather be described in terms of affective and embodied epistemology, a holistic spirituality, and a non-reductionistic worldview (Yong 2005b:64), as a criticism on what it perceived as the pretentiousness of the scientific mind (Johns 1999:191).

Pentecostal scholars in the course of the 20th century kept themselves occupied with issues that mattered for Pentecostals, like Spirit baptism, glossolalia, sanctification, Pentecostal distinctives, Pentecostal hermeneutics, leadership, and church government (Chan 2010:142). In the last few decades these debates have been integrated into multidisciplinary and ecumenical conversations (Vondey 2013:152). The result is that the horizon of Pentecostal theological scholarship has moved from a church-dominated audience to a dialogue partner with the academe and society (Butler 2005:347). The new expansion of Pentecostal theological

19.The inevitability is linked to the growth and influence of Pentecostal churches in South Africa. 'The Pentecostal movement is by far the largest and most important religious movement to originate...This explosive growth has forced the Christian world to pay increasing attention to the entire movement and to attempt to discover the root cause of this growth" (Synan 2006.1). Pentecostalism today accounts for the vast majority of Christians in South Africa (Anderson 2000:14, 2001:27; Nel 2005:202-203). Around half of Southern African Christians today are adherents of the Zionist/Pentecostalist legacy of Lake (Morton 2012:98). 
scholarship has become known by some as 'Renewal studies' (Gräbe 2005:124-129) to describe a Spirit-oriented perspective on life (Asamoah-Gyadu 2015:18). What is important in Renewal studies is not Pentecostalism but Pentecost, indicating the renewing work of the Spirit (Gräbe 2005:125). The pneumatological motif is based on the experiential and represents a procedure where interaction and dialogue are enriched by what the Spirit is saying (Yong 2009:xvi). The person and work of the Spirit is central in the Renewal theology (Williams 1996) and it is taking Pentecostal theological scholarship to religion, science, and technology to open new frontiers in thinking (Vondey 2010a:192-196).

\section{Conclusion}

The first five or six decades of the existence of South African Pentecostalism is characterised by anti-intellectualism that is based on the historical given of the movement's origin, with most of the early members being illiterate and lacking the motivation to engage in intellectual activities and organisations. Its anti-intellectualism is also driven by the urgency and determination of Pentecostals to proclaim the gospel of salvation to a world facing the imminent second coming with its judgement seat; there was no time left for training and preparation. Early Pentecostals also perceived that an intellectualisation of the Christian faith was resisting or even suppressing the work of the Holy Spirit, while the life of the Spirit and the demands of intellectual labours were seen as opposites that do not readily mix.

Pentecostal anti-intellectuality rests on the observations that Pentecostal spirituality arises from the affections rather than intellectual ability; it is dominated by imagination rather than reason; it operates on the level of oral rather than written discourse; and it is concerned with ongoing, daily revelation of truths in the life of the individual and assembly rather than the revelation of eternal truths.

From the 1970s a new tradition originated in South African Pentecostalism, Pentecostal theological scholarship with its intellectual participation that is experiential and defined by the foundational dimension of an encounter with the Spirit that determines Pentecostal spirituality and praxis. It operates on the principle of play rather than performance. It is embodied scholarship, requiring the scholar going beyond the mere intellectual pursuit of knowledge to participate actively in the community of faith. And it is based on a comprehensive, analogical hermeneutic where the present is interpreted in terms of the past, the Christian life in terms of biblical narratives, and the Pentecostal experience in terms of the Day of Pentecost and the experiences of the earliest Church (Archer 2012:110).

Contemporary Pentecostalism is neither anti-intellectual nor intellectual; both elements are present among Pentecostals worldwide and in South Africa, and Pentecostal theological scholarship experiences to a certain extent tension with antiintellectual strains within Pentecostalism. The coexistence of both trends is essential if one desires to come to terms with the scope and depth of the Pentecostal ethos with its emphasis on the experiential and lived reality. Pentecostal theological scholarship can rather be described in terms of affective and embodied epistemology, a holistic spirituality, and a nonreductionistic worldview as a criticism on what it perceived as the pretentiousness of the scientific mind.

\section{Acknowledgements Competing interests}

The author declares that he has no financial or personal relationships which may have inappropriately influenced him in writing this article.

\section{References}

Albrecht, D.E., 1999, Rites in the Spirit: A ritual approach to Pentecostal/charismatic spirituality, JPT Supp, 17, Sheffield Academic Press, Sheffield.

Anderson, A., 2000, Zion and Pentecost: The spirituality and experience of Pentecostals and Zionist/Apostolic churches in South Africa, African Initiatives in Christian Mission, University of South Africa, Pretoria.

Anderson, A., 2001, African reformation: African Initiated Churches in the 20th century, Africa World Press, Trenton, NJ.

Anderson, A., 2007, Spreading fires: The missionary nature of early Pentecostalism, Orbis, Maryknoll.

Anderson, A.H., 2012, 'Origins', in A. Stewart (ed.), Handbook of Pentecostal Christianity, pp. 162-166, Northern Illinois University Press, DeKalb, IL.

Anderson, R.M., 1979, Vision of the disinherited: The making of American Pentecostalism, Hendrickson, Peabody, MA.

Apostolic Faith Mission of South Africa, 1961, Constitution of the AFM of SA, Gospel Publishers, Johannesburg.

Archer, K.J., 2009, A Pentecostal hermeneutic: Spirit, Scripture and community, CPT, Cleveland, $\mathrm{OH}$.

Archer, K.J., 2012, 'Hermeneutics', in A. Stewart (ed.), Handbook of Pentecosta Christianity, pp. 108-116, Northern Illinois University Press, DeKalb, IL.

Asamoah-Gyadu, J.K., 2005, African charismatics: Current developments within independent indigenous Pentecostalism in Ghana, Studies of Religion in Africa, 27, Brill, Leiden.

Asamoah-Gyadu, J.K., 2013, Contemporary Pentecostal Christianity: Interpretations from an African context, Wipf \& Stock, Eugene, OR.

Asamoah-Gyadu, J.K., 2015, Sighs and signs of the Spirit: Ghanaian perspectives on Pentecostalism and renewal in Africa, Regnum Studies in Mission, Regnum, Oxford.

Barr, J., 1983, Holy Scripture: Canon authority criticism, Clarendon, Oxford.

Becker, M., 2004, 'A tenet under examination: Reflections on the Pentecostal hermeneutical approach', The Journal of the European Pentecostal Theological Association 24, 30-48. http://dx.doi.org/10.1179/jep.2004.24.1.004

Burger, I. \& Nel, M., 2008, The fire falls in Africa: A history of the Apostolic Faith Mission of South Africa, CUM, Vereeniging.

Burger, I.S.V.D.M., 1987, Geloofsgeskiedenis van die Apostoliese Geloofsending van Suid-Afrika 1908-1958, Published DD dissertation, University of Pretoria, Evangelie Uitgewers, Johannesburg.

Butler, A., 2005, 'Pentecostal traditions we should pass on: The good, the bad and the ugly', Pneuma 27(2), 343-353. http://dx.doi.org/10.1163/157007405774857391

Carstens, J., 2014, The first commission: My work my worship, I-Opus Institute, Meyersdal.

Cartledge, M.J., 2003, Practical Theology: Charismatic and empirical perspectives, Studies in Pentecostal and Charismatic Issues, Paternoster, Carlisle.

Cartledge, M.J., 2012, 'Glossolalia', in A. Stewart (ed.), Handbook of Pentecostal Christianity, pp. 94-97, Northern Illinois University Press, DeKalb, IL.

Chan, S., 2000, Pentecostal theology and the Christian spiritual tradition, JPT Supp, 21, Sheffield Academic Press, Sheffield.

Chan, S., 2010, 'Jesus as Spirit-baptizer: Its significance for Pentecostal ecclesiology', in J.C. Thomas (ed.), Toward a Pentecostal ecclesiology: The church and the fivefold gospel, pp. 139-156, CPT, Cleveland, $\mathrm{OH}$.

Chandomba, L., 2007, The history of Apostolic Faith Mission and other Pentecosta missions in South Africa, Authorhouse, Keynes.

Clark, M., 2015, 'Contemporary Pentecostal leadership: The Apostolic Faith Mission of South Africa as case study', Cyberjournal for Pentecostal-Charismatic Research 16, 1-14, viewed 12 September 2015, from http://www.pctii.org/cyberj/cyberj16/ clark.html

Clarke, C.R., 2013, 'Old wine and new wine skins: West Indian and the new West African Pentecostal churches in Britain and the challenge of renewal', in H.D. African Pentecostal churches in Britain and the challenge of renewal', in H.D.
Hunter \& N. Ormerod (eds.), The many faces of global Pentecostalism, pp. 169-182, $\mathrm{CPT}$, Cleveland, $\mathrm{OH}$. 
Cox, H., 1995, Fire from heaven: The rise of Pentecostal spirituality and the reshaping of religion in the twenty-first century, Reading, Addison-Wesley, MI.

Daniels, D.D., 2005, 'Wonder and scholarship': Reflecting on Jacobsen and Jacobsen's scholarship and Christian faith. Enlarging the conversation', Pneuma 27(1), 110-114. http://dx.doi.org/10.1163/157007405774270356

De Wet, C., 1986, 'The challenge of signs and wonders in world missions for the twentieth century', in L.G. McClung (ed.), Azusa Street and beyond: Pentecostal missions and church growth in the twentieth century, pp. 160-165, Bridge, South Plainfield, NJ.

Du Plessis, L., 1984, Pinksterpanorama: 'n Geskiedenis van die Volle Evangelie-Kerk van God in Suidelike Afrika, VEK, Irene.

Faupel, D.W., 1996, The everlasting gospel: The significance of eschatology in the development of Pentecostal thought, JPT Supp, 10, Sheffield Academic Press, Sheffield.

Gabriel, A.K., 2012, 'Neo-Pentecostalism', in A. Stewart (ed.), Handbook of Pentecostal spirituality, pp. 150-154, Northern Illinois University Press, DeKalb, IL.

Gee, D., 1932, Pentecost, Gospel Publishing House, Springfield, MO.

Giliomee, H. \& Mbenga, B., 2007, New history of South Africa, Tafelberg, Cape Town.

Goff, C.W., 2008, Measuring the clergy/laity gap and its effect on church health and outreach, Pro Quest, Eisenhower, MI

Gräbe, P., 2005, 'A perspective from Regent University's Ph.D. program in renewal studies: Theology in the light of the renewing work of the Holy Spirit', Pneuma 27(2), 124-129. http://dx.doi.org/10.1163/157007405774270248

Hammonds, R., 2009, The Pentecostal movement, Authorhouse, Bloomington, IL.

Harper, M., 2008, 'The waves keep coming in', The Journal of the European Pentecostal TheologicalAssociation 28(2), 102-117. http://dx.doi.org/10.1179/jep.2008.28.2.002

Hollenweger, W.J., 1972, The Pentecostals: The charismatic movement in the churches, Augsburg, Minneapolis, MN.

Hollenweger, W.J., 1986, 'After twenty years' research on Pentecostalism', International Review of Missions 75(297), 3-12. http://dx.doi.org/10.1111/j.1758-6631.1986. tb01446.x

Hollenweger, W.J., 1992, 'Pentecostalism and academic theology: From confrontation to cooperation', Epta Bulletin 11(1\&2), 42-49.

Hollenweger, W.J., 2005, Pentecostalism: Origins and developments worldwide, Baker Academic, Grand Rapids, MI.

Holter, H., 2010, 'When biblical scholars talk about "global" biblical interpretation', in K. Holter \& L.C. Jonker (eds.), Global hermeneutics? Reflections and consequences, pp. 85-93, SBL International Voices in Biblical Studies, Society of Biblical Literature, Atlanta, GA

Hunt, S.J., 2002, 'Deprivation and Western Pentecostalism revisited: The case of "classical" Pentecostalism', PentecoStudies 1(1), 1-32, viewed 12 Septembe 2015, from http://www.equinoxpub.com/journals/index.php/PENT/issue/archive

Jacobsen, D., 2003, Thinking in the Spirit: Theologies of the early Pentecostal movement, Indiana University Press, Bloomington, IL.

Janse van Rensburg, F. \& Nel, M., 2015, 'The long and arduous journey of theological training in the AFM of SA', To be published in In Luce Verbi and as part of Festschrift for prof Fika Janse van Rensburg, North-West University, Potchefstroom.

Johns, C.B., 1993, Pentecostal formation: A pedagogy among the oppressed, JPT Supp, 3. Sheffield Academic Press, Sheffield.

Johns, C.B., 1999, 'Partners in scandal: Wesleyan and Pentecostal scholarship', Pneuma 21(2), 183-197. http://dx.doi.org/10.1163/157007499X00134

Karkkainen, V.M., 1998, 'Pentecostal hermeneutics in the making: On the way from fundamentalism to Postmodernism', The Journal of the European Pentecosta Theological Association 18, 76-115. http://dx.doi.org/10.1179/jep.1998.18.1.006

Kay, W.K. \& Dyer, A.E. (eds.), 2004, Pentecostal and charismatic studies: A reader, SCM, London.

King, G.W., 2008, 'Streams of convergence: The Pentecostal-fundamentalist response to modernism', PentecoStudies 7(2),64-84, viewed 12 September 2015, from http://www.equinoxpub.com/journals/index.php/PENT/issue/archive

Land, S.J., 1993, Pentecostal spirituality: A passion for the kingdom, JPT Supp. 10, Sheffield Academic Press, Sheffield.

Langerman, J.L., 1983, 'Apostolic faith mission of South Africa: A revitalization of the theological concepts of church ministry', Unpublished DMin dissertation, Fulle Theological Seminary.

Lederle, H.I., 1988, Treasures old and new: Interpretation of "Spirit-baptism" in the charismatic renewal movement, Hendrickson, Peabody, MA.

Liardon, R., 1996, God's generals: Why they succeeded and why some failed, Whitaker House, New Kensington, PA.

Lindsay, G., 1971, The new John G. Lake sermons, Christ for the Nations, Dallas, TX.

Macchia, F., 1992, 'Sighs too deep for words: Toward a theology of glossolalia', Journal of PentecostalTheology1,47-73.http://dx.doi.org/10.1177/096673699200100105

Macchia, F.D., 2006, 'The Kingdom and the Power', in M. Welker (ed.), The work of the Spirit: Pneumatology and Pentecostalism, pp. 101-119, William B. Eerdmans, Grand Rapids, MI.

Macchia, F.D., 2010, 'The church of the latter rain: The church and eschatology in Pentecostal perspective', in J.C. Thomas (ed.), Toward a Pentecostal ecclesiology: The church and the fivefold gospel, pp. 248-259, CPT, Cleveland, OH.

McClung, G., 2012, 'Introduction: "Try to get people saved: Azusa Street missiology"', in F. Mc Clung (ed.), Azusa Street \& beyond: Missional commentary on the global Pentecostal/charismatic movement, pp. 1-22, Bridge-Logos, Alachua, FL.
McClung, L.G. \& Wagner, C.P., 1986, Azusa Street and beyond: Pentecostal missions and church growth in the twentieth century, Bridge Publishing, Southfield, MI.

McGee, G.B., 1986, 'Early Pentecostal missionaries', in L.G. McClung (ed.), Azusa Street and beyond: Pentecostal missions and church growth in the twentieth century, pp. 32-38, Bridge, South Plainfield, NJ.

McGee, G.B., 2010, Miracles, missions, and American Pentecostalism, Orbis, Maryknoll.

McQueen, L., 2009, Joel and the Spirit: The cry of a prophetic hermeneutic, CPT, Cleveland, $\mathrm{OH}$.

Menzies, W.M., 2007, 'The reformed roots of Pentecostalism', PentecoStudies 6(2) 78-99, viewed 12 September 2015, from http://www.equinoxpub.com/journals/ index.php/PENT/issue/archive

Mittelstadt, M.W., 2010, Reading Luke-acts in the Pentecostal tradition, CPT, Cleveland, OH.

Mittelstadt, M.W., 2012, 'Academic societies', in A. Stewart (ed.), Handbook of Pentecostal Christianity, pp. 9-13, Northern Illinois University Press, DeKalb, IL.

Möller, F.P., 1975, Die diskussie oor die charismata soos wat dit in die Pinksterbeweging geleer en beoefen word, Evangelie Uitgewers, Braamfontein.

Molobi, V., 2014, 'Living in the townships: An appraisal of Pentecostal social ministry in Tshwane', HTS Teologiese Studies/Theological Studies 70(3), Art. \#2791, 9 pages. http://dx.doi.org/10.4102/hts.v70i3.2791

Moore, R.D., 1987, 'A Pentecostal approach to scripture', Seminary Viewpoint 8(1), $4-11$.

Moore, R.D., Land, S.J. \& Thomas, J.C., 1992, 'Editorial', Journal of Pentecostal Theology 1, 3-5. http://dx.doi.org/10.1177/096673699200100102

Morton, B., 2012, "'The devil who heals": Fraud and falsification in the evangelical career of John G Lake, missionary to South Africa 1908-1913', African Historical Review 44(2), 98-118. http://dx.doi.org/10.1080/17532523.2012.739752

Naňez, R.M., 2005, Full gospel, fractured minds? A call to use God's gift of the intellect, Eerdmans, Grand Rapids, MI.

Nel, M., 2005, 'P.L. le Roux, Dutch Reformed missionary, Zionist preacher and leade of the Apostolic Faith Mission of South Africa, and the origin of some of the African Independent Churches in Southern Africa. Part 2', Studia Historiae Ecclesiasticae 31(1), 127-143.

Nel, M., 2015, 'Attempting to define a Pentecostal hermeneutic', Scriptura 114, 21 pages. http://dx.doi.org/10.7833/114-0-1044, viewed 08 January 2015, from http://scriptura.journals.ac.za/pub/article/view/1044

Neumann, P.D., 2012, 'Spirituality', in A. Stewart (ed.), Handbook of Pentecosta Christianity, pp. 195-201, Northern Illinois University Press, DeKalb, IL.

Niebuhr, R., 1929, Social sources of denominationalism World Publishing, New York.

Nienkirchen, C.W., 1992, A.B. Simpson and the Pentecostal movement, Hendrickson, Peabody, MA.

Noll, M.A., 1994, The scandal of the Evangelical mind, Eerdmans, Grand Rapids, MI. Parham, C., 1930, The life of Charles F. Parham, Commercial Printing, Birmingham.

Peretti, F., 1995, The oath, WestBow, Nashville, TN.

Phillips, G.Y., Janse van Rensburg, F. \& Van Rooy, H.F., 2012, 'Developing an integrated approach to interpret New Testament use of the Old Testament', In die Skriflig/In Luce Verbi 46(2), Art. \#50, 10 pages. http://dx.doi.org/10.4102/ids. v46i2.50

Plüss, J.D., 2003, 'Religious experience in worship: A Pentecostal perspective', PentecoStudies 2(1), 1-21, viewed 12 September 2015, from http://www. equinoxpub.com/journals/index.php/PENT/issue/archive

Price, L., 1999, 'Scholarship and evangelism: Oil and water?', in A.H. Anderson \& W.J Hollenweger (eds.), Pentecostals after a century: Global perspectives on a movement in transition, pp. 197-208, Sheffield Academic Press, Sheffield.

Rance, D., 2008, 'Fulfilling the apostolic mandate in apostolic power: Seeking a Spiritdriven missiology and praxis', Unpublished paper presented at the 38th Annual Meeting of the Society for Pentecostal Studies, pp. 1-25.

Richie, T., 2006, "'The unity of the Spirit": Are Pentecostals inherently ecumenists and inclusivists?', Journal of the European Pentecostal Theological Association 26(1) 21-35. http://dx.doi.org/10.1179/jep.2006.26.1.003

Robeck, C.M., 2004, 'An emerging magisterium? The case of the Assemblies of God', in W. Ma \& R.P. Menzies (eds.), The Spirit and spirituality: Essays in honour of Russell P. Spittler, pp. 212-224, T\&T Clark, London.

Robeck, C.M., 2006, The Azusa Street Mission and Revival: The birth of the global Pentecostal movement, Thomas Nelson, Nashville, TN.

Smith, J.K.A., 2010, Thinking in tongues: Pentecostal contributions to Christian philosophy, Pentecostal Manifestoes, 2, Eerdmans, Grand Rapids, MI.

Smith, J.K.A. \& Yong, A. (eds.), 2010, Science and the Spirit: A Pentecostal engagement with the sciences, Indiana University Press, Bloomington, IL.

Spawn, K.L., 2011, 'The principle of analogy and biblical interpretation in the Renewal tradition', in K.L. Spawn \& A.T. Wright (eds.), Spirit and scripture: Examining a pneumatic hermeneutic, pp. 31-52, Continuum, New York.

Spurling, R.G., 1920, The lost link, R.G. Spurling, Turtletown, TN.

Stephenson, C.A., 2009, 'Pentecostal theology according to the theologians: An introduction to the theological methods of Pentecostal systematic theologians', DPhil dissertation, Graduate School, Marquette University.

Stibbe, M., 1998, 'This is that: Some thoughts concerning charismatic hermeneutics', Anvil 13(3), 181-193.

Synan, V., 1971, The Holiness-Pentecostal movements in the United States, William B. Eerdmans, Grand Rapids, MI. 
Synan, V., 1997, The Holiness-Pentecostal tradition: Charismatic movements in the twentieth century, 2 nd edn., Eerdmans, Grand Rapids, MI.

Synan, V., 2001, The century of the Holy Spirit: 100 years of Pentecostal and charismatic renewal, 1901-2001, Thomas Nelson, Nashville, TN.

Synan, V., 2006, 'The origins of the Pentecostal movement', pp. 1-7, viewed 2 May 2015, from http://www.oru.edu/library/special_collections/holy_spirit_research_ center/Pentecostal_history.php

Tarr, D., 1997, 'Transcendence, immanence, and the emerging Pentecostal academy', in W. Ma \& R.P. Menzies (eds.), Pentecostalism in context: Essays in honor of William W. Menzies, pp. 195-222, Sheffield Academic Press, Sheffield.

Thomas, J.C., 2010, The devil, disease and deliverance: Origins of illness in New Testament thought, CPT, Cleveland, OH.

Tickle, P., 2012, Emergence Christianity: What it is, where it is going, and why it matters, BakerBooks, Grand Rapids, MI.

Togarasei, L., 2015, 'Modern/charismatic Pentecostalism as a form of "religious" secularisation in Africa', Studia Historiae Ecclesiasticae 41(1), 56-66. http://dx. doi.org/10.17159/2412-4265/2015/v41n1a5

Tomberlin, D., 2010, Pentecostal sacraments: Encountering God at the altar, CPLC, Cleveland, $\mathrm{OH}$.

Tomlinson, A.J., 1913, The last great conflict, Walter E. Rogers, Cleveland, OH.

Turnage, M., 2003, 'The early church and the axis of history and Pentecostalism: Facing the 21st century. Some reflections', Journal of the European Pentecostal Theological Association 23, 4-29. http://dx.doi.org/10.1179/jep.2003.23.1.002

Van Staden, A.J., 1980, Die Apostoliese Geloof Sending van Suid-Afrika: Hulle leer getoets aan die Skrif, HAUM, Pretoria.

Vondey, W., 2010a, Beyond Pentecostalism: The crisis of global Christianity and the renewal of the theological agenda, Pentecostal Manifestos, 1, Eerdmans, Grand Rapids, MI.

Vondey, W., 2010b, 'Does God have a place in the physical universe? Physics and the quest for the Holy Spirit', in J.K.A. Smith \& A. Yong (eds.), Science and the Spirit: A Pentecostal engagement with the sciences, pp. 75-91, Indiana University Press, Bloomington, IL.

Vondey, W., 2013, Pentecostalism, Bloomsbury, London.

Vondey, W. \& Green, C.W., 2010, 'Between this and that: Reality and sacramentality in the Pentecostal worldview', Journal of Pentecostal Theology 19(2), 243-264.
Vreeland, D., 2002, 'Edward Irving: Preacher, prophet \& charismatic theologian', Pneuma Review 5(2), 1-10, viewed 12 September 2015, from http://pneumareview. com/edward-irving-preacher-prophet-and-charismatic-theologian/

Wacker, G., 2001, Heaven below: Early Pentecostals and American culture, Harvard University Press, Cambridge.

Walker, A., 1993., 'Pentecostalism and charismatic Christianity', in A.E. McGrath (ed.), The Blackwell Encyclopedia of modern Christian thought, pp. 428-434, Blackwell, Oxford.

Wariboko, N., 2011, The Pentecostal principle: Ethical methodology in new spirit, Pentecostal Manifestoes, 5, Eerdmans, Grand Rapids, MI.

Warrington, K., 2008, Pentecostal theology: A theology of encounter, Continuum, New York.

Wenk, M., 2003, 'Do we need a distinct European Pentecostal/Charismatic approach to theological education?', The Journal of the European Pentecostal Theological Association 33, 58-71. http://dx.doi.org/10.1179/jep.2003.23.1.005

Wenk, M., 2004, 'Book review: Mark J. Cartledge, practical theology: Charismatic and empirical perspectives', The Journal of the European Pentecostal Theological Association 24, 122-125.

Wessels, W.J., 1992, 'Skrifgebruik en samelewing: Die Apostoliese Geloofsending van Suid-Afrika', In die Skriflig 26(3), 369-384. http://dx.doi.org/10.4102/ids.v26i3.1422

Williams, J.R., 1996, Renewal theology: Systematic theology from a charismatic perspective, 3 volumes in one, Zondervan, Grand Rapids, MI.

Work, T., 2010, 'What have Galapagos to do with Jerusalem? Scientific knowledge in theological context', in J.K.A. Smith \& A. Yong (eds.), Science and the Spirit: $A$ Pentecostal engagement with the sciences, pp. 15-33, Indiana University Press, Bloomington, IL.

Yong, A., 2003, Spirit-word-community: Theological hermeneutics in trinitarian perspective, Wipf and Stock, Eugene, OR.

Yong, A., 2005a, The Spirit poured out on all flesh: Pentecostalism and the possibility of global theology, Baker Academic, Grand Rapids, MI.

Yong, A., 2005b, 'Academic glossolalia? Pentecostal scholarship, multi-disciplinarity, and the science-religion conversation', Journal of Pentecostal Theology 14(1), 61-80. http://dx.doi.org/10.1177/0966736905056544

Yong, A., 2007, 'Pentecostals and the theological academy', Theology Today 64(2), 244-250. http://dx.doi.org/10.1177/004057360706400209

Yong, A., 2009, 'Introduction', in A. Yong (ed.), The Spirit renews the face of the earth Pentecostal forays in science and theology of creation, pp. i-xvii, Pickwick, Eugene, OR. 